해양심층수로 배양한 해양미세조류 Tetraselmis sp. JK-46의 성분 조성 및 생리활성

주동식*·김광우 ${ }^{1} \cdot$ 조순영 ${ }^{1}$

한중대학교 외식산업학과, ${ }^{1}$ 강릉대학교 식품과학과

\title{
Physiological Properties of Extracts and the Chemical Composition of Tetraselmis sp. JK-46 Cultured with Deep Seawater
}

\author{
Dong-Sik Joo*, Kwang-Woo $\mathrm{Kim}^{1}$ and Soon-Yeong Cho ${ }^{1}$ \\ Deprtment of Foodservice Industry, Hanzhong University, Donghae 240-713, Korea \\ ${ }^{1}$ Deprtment of Food Science, Kangnung National University, Gangneung 210-702, Korea
}

This study examined Tetraselmis sp. JK-46 isolated from seawater from the East Sea. Deep seawater (DSW) had a greater effect on the growth of Tetraselmis sp. JK-46 than surface seawater (SSW). The crude protein, lipid, carbohydrate and ash contents of Tetraselmis sp. JK-46 cultured with DSW were 27.2, 37.1, 13.2 and $26.3 \%$, respectively, and these values were similar to the results for samples cultured with SSW. The contents of $\mathrm{Mg}, \mathrm{Ca}, \mathrm{Fe}$ and $\mathrm{K}$ in the DSW cultured samples were 7080.3, 1009.6, 251.2, and 2749.7 $\mathrm{mg} / 100 \mathrm{~g}$, respectively. The fatty acid compositions of Tetraselmis sp. JK-46 cultured with DSW and SSW were 53.7 and $49.0 \%$ polyunsaturated fatty acids (PUFA) and 25.7 and $30.7 \%$ saturated fatty acids (SFA), respectively. The total amino acid contents of the samples cultured with DSW and SSW were 7392.6 and $6376.0 \mathrm{mg} / 100 \mathrm{~g}$ respectively. The 1,1-diphenyl-2-picrylhydrazyl (DPPH) radical scavenging activity of Tetraselmis sp. JK-46 extracts increased with the concentration of the chloroform and ethyl acetate fractions. The half maximal inhibitiory concentrations $\left(\mathrm{IC}_{50}\right)$ of the chloroform and ethyl acetate fractions of DSW and SSW cultured samples were 1.2 and $2.6 \mathrm{mg} / \mathrm{mL}$, and 3.1 and $3.3 \mathrm{mg} / \mathrm{mL}$, respectively. The ethyl acetate fractions of DSW and SSW cultured samples has anticoagulant activity and the activated partial thromboplastin times (APTT) were 93.4 and 89.3 sec., respectively. The chloroform and ethyl acetate fractions showed antimicrobial activity against Bacillus subtilis, Escherichia coli and Candida albicans.

Key words: Tetraselmis sp. JK-46, Deep seawater (DSW), Surface seawater (SSW), Physiological properties

서 론

미세조류는 당질, 지질, 단백질, 색소, 비타민, 스테로이드 및 기타 의약성분 등과 같은 유용성분뿐만 아니라 수소, 탄화 수소, 생화학 연료 등의 다양한 물질들을 생산한다. 최근 국내 외에서는 미세조류의 자원학적 잠재성에 대해 많은 논의와 연구가 진행되고 있으며 생명공학의 새로운 영역으로 인식되 고 있다 (Borowitzka, 1997; Kim et al., 2001). 특히, 미세조류의 산업적 이용에 대한 접근이 다양하게 이루어지고 있으며, 대 체에너지원, 식품, 건강보조식품, 수산양식용 사료, 의약 원료 물질, 생화학물질 등 그 응용분야가 넓어지고 있다. 식품 및 사료 용도로는 산업적 생산이 이루어지고 있으며, 미세조류 분리 및 물질 탐색, 대량생산 기술 등이 지속적으로 개발된다 면 생리활성물질의 산업적 생산도 이루어질 수 있을 것으로 기대된다 (Laurent et al., 2005).

한편, 해양심층수는 태양광이 도달하지 않는 수심 $200 \mathrm{~m}$ 이상의 깊은 곳에 있는 해수로서, 연중 수온이 $2^{\circ} \mathrm{C}$ 이하의 저온 성과 해양식물의 생장에 필수적인 영양염류가 풍부하고 병원

\footnotetext{
*Corresponding author: dsjoo777@hanzhong.ac.kr
}

균이 거의 없는 청정성을 특징으로 하는 풍부한 해양자원이다 (Korea ocean reserch lab. 2000; Takahashi, 2001). 이미 일본에서 는 해양심층수의 특성을 이용한 수산양식, 식품, 음료수, 의학 및 화장품 등 다양한 분야에서 이용되거나 상품이 개발되어 판매되고 있다. 국내에서도 강원도 동해안 및 울릉도를 중심으 로 해양심층수 개발 및 해양심층수의 이용에 대한 연구가 활발 하게 진행되고 있으며, 염분을 제거한 미네랄수가 미래의 수자 원으로서 역할을 할 것으로 여겨진다 (Kim et al., 2003).

한편, 강원도 동해안은 남서해안과 다른 해양환경으로 인 해 구별된 해양생물군이 분포되어 있으며, 이는 해양에 존재 하는 미세조류와 이들 미세조류의 생화학적 성상도 차이가 있을 것으로 여겨진다.

따라서 본 연구에서는 강원도 동해안 해양환경으로부터 미세조류를 분리하고, 분리된 미세조류를 해양심층수와 표층 수로 배양하면서 해양심층수의 미세조류 배양에의 효과를 확인하였다. 아울러 해양심층수와 표층수로 배양한 미세조류 의 성분을 비교하였고, 이들 성분의 생리활성을 비교하여 해 양심층수의 미세조류 배양 소재로서의 가능성을 확인하였다. 


\section{재료 및 방법}

재료

동해안 지역 (울진, 삼척, 동해, 강릉, 속초 등)의 수심 5 , 15,20 및 $25 \mathrm{~m}$ 의 해수를 채수하여 미세조류를 분리하는데 사용하였다. 총 85 개의 해수 시료로부터 해양미세조류 1종 (Tetraselmis sp. JK-46)을 분리하여 본 실험에 사용하였다. 분리 된 미세조류의 배양에 사용된 해양심층수는 (주)울릉미네랄 (수심: $650 \mathrm{~m}$ )에서 공급받아 사용하였으며, 표층수는 강릉지역 해안에서 채수하여 사용하였다. 생리활성물질 추출에 이용한 Tetraselmis sp. JK-46 배양 조체는 진공동결건조기 (FreeZone plus-6 Cascade Freeze Dry system, Labconco, USA)로 건조하여 $-40^{\circ} \mathrm{C}$ 에 보관하면서 사용하였다.

\section{배지 및 배양 방법}

Tetraselmis sp. JK-46의 배양은 f/2배지 (Guillard, 1975)를 기본 배양 배지로 사용하였으며, 해수는 해양심층수와 표층수 를 각각 사용하였다. 미세조류의 배양은 실린더 배양기 (Ø9 $\mathrm{cm} \times \mathrm{L} 90 \mathrm{~cm}$ )을 이용하였고, 배양시 별도로 탄소를 공급하지 않고 공기량 $(30 \mathrm{~L} / \mathrm{min})$ 을 조절하였고, 배양온도 및 빛 강도는 각각 $25 \pm 2^{\circ} \mathrm{C}, 7,000 \mathrm{lux}$ 의 조건에서 배양하였다.

$\mathrm{pH}$ 측정

$\mathrm{pH}$ 측정은 배지에 미세조류를 접종한 시점부터 매 24시간 마다 $\mathrm{pH}$ meter (Mettler Toledo, SevenEasy pH, Switzerland)로 측정하였다.

\section{조체량 측정}

조체량 측정은 배지에 미세조류를 접종한 시점부터 매 24시 간마다 $5 \mathrm{~mL}$ 의 시료를 취하여 microfilter paper (Ø $0.45 \mu \mathrm{m})$ 로 여과한 후, $0.85 \%$ 생리식염수 $10 \mathrm{~mL}$ 로 수세한 다음 2 시간 건조 $\left(100^{\circ} \mathrm{C}\right)$ 한 후에 30 분 방냉하여 무게를 측정하였다. 조체 의 성장은 초기 조체 무게에 대한 측정 시점의 조체 무게비의 대수 $[\ln (\mathrm{x} / \mathrm{xo})]$ 로 나타내어 초기 조체 농도에 대한 경시적 변화를 측정하였다.

일반성분 분석

일반성분은 $\mathrm{AOAC}$ 법 (1995)에 따라 수분은 상압가열건조 법, 조지방은 Soxthlet법, 회분은 건식회화법으로 측정하였으 며, 조단백질은 semimicro Kjeldahl법으로 질소를 정량한 후 질소계수 $(6.25)$ 를 이용하여 계산하였다.

\section{무기질 정량분석}

$\mathrm{Ca}, \mathrm{Mg}, \mathrm{K}, \mathrm{Al}, \mathrm{Fe}, \mathrm{Mn}, \mathrm{Zn}, \mathrm{Cu}$ 등 무기질 분석은 동결건조 시료 약 $0.5 \sim 1.0 \mathrm{~g}$ 취하여 진한 질산 $12 \mathrm{~mL}$ 를 가한 후 microwave로 1 시간동안 분해하고 냉각시킨 후, 3 차 증류수로 $50 \mathrm{~mL}$ fill-up하여 ICP-OES (PerkinElmer precisely optical Emission spectrometer, Optima 5300 DV USA)로 분석하였다.

지방산 조성분석

지방산 조성분석은 직접 전환 에스테르법 (Dionisi et al.,
1993)을 이용하여 측정하였다. 즉, 동결건조한 미세조류 0.5 $\mathrm{g}$ 에 $\mathrm{MeOH}$ : Chloroform : $\mathrm{HCl}$ (10:1:1) 혼합 용매 $6 \mathrm{~mL}$ 를 첨가하여 추출과 동시에 $80^{\circ} \mathrm{C}$ 에서 1 시간 가열하여 메틸화하 였다. 냉각한 다음 $1 \mathrm{~mL}$ 의 증류수를 첨가한 후 추출 용매 (hexane : Chloroform $=4: 1$ ) $2 \mathrm{~mL}$ 를 첨가하여 메틸화 성분을 추출하였다. 추출된 지용성 획분을 $\mathrm{Na}_{2} \mathrm{SO}_{4}$ 로 탈수시켜 $\mathrm{GC}$ (HP 6890 series, GC system USA)로 분석하였다.

아미노산 조성분석

미세조류의 총아미노산 분석은 동결건조한 시료 $50 \mathrm{mg}$ 을 glass tube에 넣고 $6 \mathrm{~N} \mathrm{HCl}$ 을 $5 \mathrm{~mL}$ 첨가한 후 $110^{\circ} \mathrm{C}$ 에서 22 시간 동안 가수분해하였다. 이 분해물을 감압건고한 후 $0.02 \mathrm{~N} \mathrm{HCl}$ 로 용해한 다음 마이크로필터 $(\varnothing 0.2 \mu \mathrm{m})$ 로 여과하여 아미노 산 자동분석기 (L-8800, High speed amino acid analyzer, Hitachi, Japan)로 분석하였다.

\section{생리활성물질의 추출 및 물질 분획}

조체로부터 물질 추출은 chloroform과 methanol을 1:1 혼합 용매를 사용하였다. 추출은 조체 $5 \sim 10 \mathrm{~g}$ 을 막자 사발에 넣고 sea sand를 $10 \mathrm{~g}$ 정도 가하고 마쇄한 후 추출 용매를 1000 $\mathrm{mL}$ 가하여 1차 추출한 다음 여과하고, 고형분은 다시 막자사 발에 넣고 충분하게 마쇄한 후 동일 용매 $100 \mathrm{~mL}$ 를 가하여 2 차 추출하였고, 동일하게 3 차 추출까지 행하였다. 추출 시료 는 진공농축기로 감압농축한 다음 $10 \mathrm{~mL}$ 추출 용매로 녹여 겔크로마토그래피용 시료로 사용하였다. 분획은 유리칼럼 (Ø5 $\mathrm{cm} \times 50 \mathrm{~cm}$ )에 chloroform으로 aging 시켜놓은 silica gel

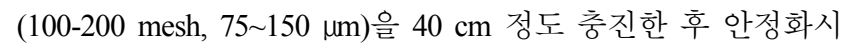
킨 다음 추출용매에 녹여놓은 $10 \mathrm{~mL}$ 를 모두 흡착시켰다. 흡착 시킨 후 hexane, chloroform, ethyl acetate 및 methanol의 순서로 각 용매 가용 획분을 분획하였다.

항산화성 (Radical Scavenging Activity, RSA) 측정

RSA는 Hatano et al. (1988)의 방법을 약간 수정하여 측정하 였다. 각 획분별로 농축한 시료를 일정한 농도가 되도록 methanol $2 \mathrm{~mL}$ 에 녹이고 이를 $1.5 \times 10^{-4} \mathrm{M}$ 1,1-diphenyl-2picrylhydrazyl (DPPH)/methanol 용액 $0.5 \mathrm{~mL}$ 와 혼합한 다음 실온에서 30 분간 방치한 후, $517 \mathrm{~nm}$ 에서 흡광도를 측정하여 다음 식으로 RSA값을 계산하였다. 대조구는 시료용액 대신에 $2 \mathrm{~mL}$ 의 methanol을 넣어 시료용액과 동일한 방법으로 흡광도 를 측정하였다.

$$
\operatorname{RSA}(\%)=\frac{\text { 대조구의 흡광도-시료의 흡광도 }}{\text { 대조구의 흡광도 }} \times 100
$$

항혈액응고활성 (APTT, Activated Partial Thromboplastin Time) 측정

항혈액응고활성은 John (1982)의 방법에 따라 정상인의 정 맥혈 $4.5 \mathrm{~mL}$ 를 채취하여 $0.5 \mathrm{~mL}$ 의 sodium citrate $(3.8 \%)$ 용액과 혼합한 다음 $1,500 \mathrm{rpm}$ 에서 5 분간 원심분리하여 혈장을 분리 하였다. 혈장 $100 \mu \mathrm{L}$ 에 시료액 $10 \mu \mathrm{L}$ 를 넣고 교반 후 37 
${ }^{\circ} \mathrm{C}$ 항온 수조에서 2 분간 가온한 후, actin $100 \mu \mathrm{L}$ 을 첨가하고 다시 $37^{\circ} \mathrm{C}$ 항온수조에서 3 분간 가온한 다음 3 분이 되는 순간 미리 $37^{\circ} \mathrm{C}$ 로 가온해둔 $0.025 \mathrm{M} \mathrm{CaCl}_{2}$ 용액 $100 \mu \mathrm{L}$ 를 넣고 스톱워치로 응고 시간 $(\mathrm{sec})$ 을 측정하였다.

항균성(paper disk 법) 측정

미세조류로부터 용매추출된 각 획분의 항균 활성은 paper disk법 (Lorian, 1991)으로 측정하였다. 즉, 멸균 petri dish에 nutrient agar를 $20 \mathrm{~mL}$ 씩 부어 평판배지를 만들고 $37^{\circ} \mathrm{C}$ 에서 12 시간 배양시킨 시험 균액을 면봉을 이용하여 petri dish 상에 도말하여 접종한 후, $20^{\circ} \mathrm{C}$ 에서 2 시간 예비 배양시켰다. 다음에 paper disk ( $8 \mathrm{~mm}$, Advance Toyo, Japan)를 평판위에 올려놓고 그 위에 추출된 시료 25 및 $45 \mu \mathrm{L}$ 를 멸균 마이크로피펫으로 가한 후 $37^{\circ} \mathrm{C}$ 로 조절된 배양기에서 배양하였다. 배양 24 48 시간 경과후 paper disk 주위의 투명환의 생성 여부로 항균성 유무를 판별하였다. 본 실험에 사용한 균주는 Bacillus subtilis KCTC1021, Escherichia coli KCTC2469, Staphylococcus aureus KCTC1621, Aspergillus niger KCTC6089, Candida albicans $\mathrm{KCTC} 7270$ 등으로 유전자은행 (KCTC)로부터 분양 받아 사용하였다.
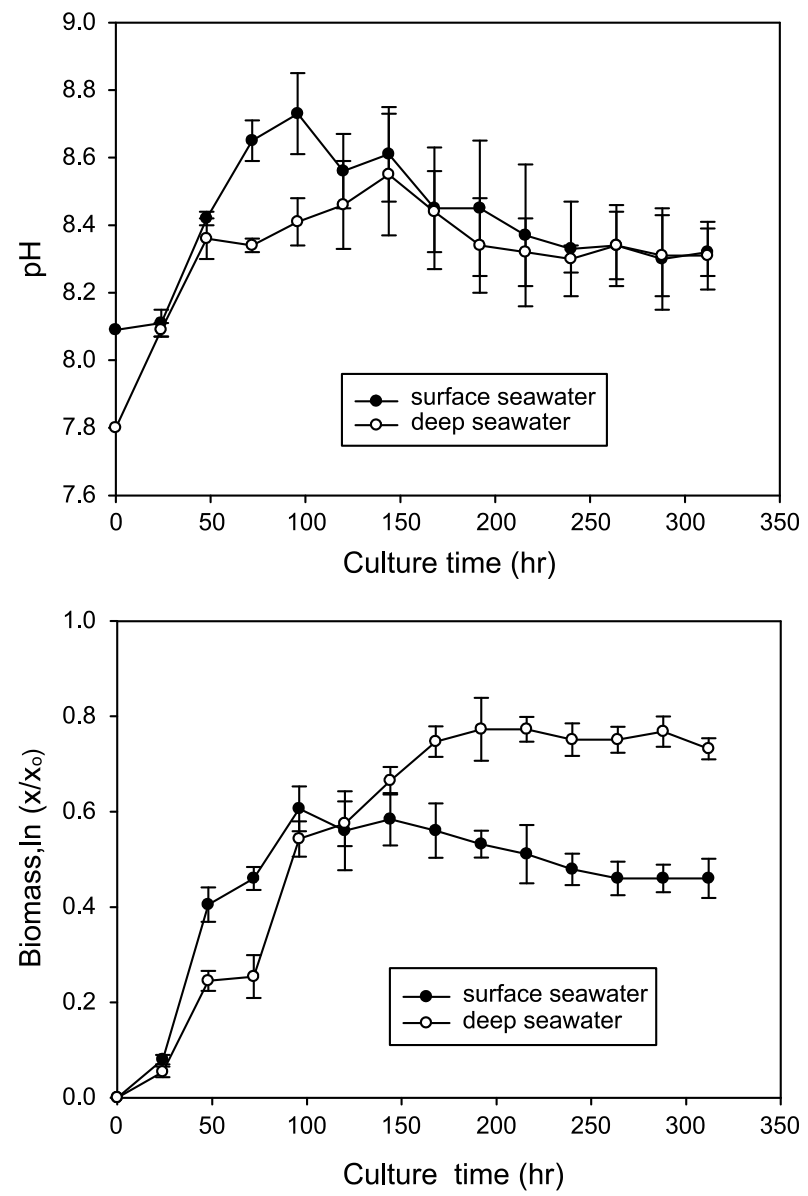

Fig. 1. Changes of $\mathrm{pH}$ and biomass of Tetraselmis sp. JK-46 using surface seawater and deep seawater as culture medium.

\section{결과 및 고찰}

Tetraselmis sp. JK-46의 배양에 해양심층수 및 표층해 수의 이용에 따른 $\mathrm{pH}$ 및 균체량의 변화

분리 미세조류를 해양심층수와 표층해수로 각각 배양하였 을 때 배양시간에 따른 $\mathrm{pH}$ 및 조체량의 변화를 Fig. 1에 나타내 었다. 해양심층수로 배양한 경우는 배양 6 일째까지 계속 증가 하여 $\mathrm{pH}$ 8.5에 도달한 후 감소하는 경향을 나타내었고, 표층해 수로 배양한 시료는 배양 4 일째에 $\mathrm{pH}$ 가 8.7로 최대값에 도달 한 후 감소하는 경향을 나타내었다. 한편, 배양시간에 따른 균체량의 변화를 살펴 본 결과, 해양심층수를 사용한 시료의 경우는 배양 8 일째까지 지속적으로 성장하여 초기 농도에 대한 균체량의 비가 0.77 까지 도달한 후 배양 13 일째까지 균체 량을 유지하는 결과를 나타내었고, 표층수를 사용한 경우에는 배양 4일째에 초기농도에 대한 균체량의 비가 0.58 로 최대에 도달한 한 후 약간씩 감소하는 경향을 나타내었다. 이러한 결과는 표층해수에 비해 해양심층수에 많이 함유되어 있는 인산염, 질산염 등의 영양염이 미세조류의 성장에 영향을 미 치는 것으로 판단되었다 (Park et al., 2001).

Table 1. Proximate compositions of Tetraselmis sp. JK-46 using surface seawater and deep seawater as culture medium

\begin{tabular}{lcc} 
& & $(\%$, dry weight $)$ \\
\hline Moisture & Surface seawater & Deep seawater \\
Crude lipid & $2.56 \pm 0.09^{*}$ & $2.32 \pm 0.04$ \\
Crude protein & $35.76 \pm 0.11$ & $37.09 \pm 0.09$ \\
Carbohydrates & $26.30 \pm 0.14$ & $27.20 \pm 0.10$ \\
Ash & $13.20 \pm 0.08$ & $12.17 \pm 0.05$ \\
\hline
\end{tabular}

* Mean \pm SD, $\mathrm{n}=3$.

Tetraselmis sp. JK-46의 성분 조성

\section{일반성분}

Tetraselmis sp. JK-46를 해양심층수와 표층해수로 각각 배 양하여 동결건조한 조체의 일반성분을 분석한 결과를 Table 1 에 나타내었다. 해양심층수와 표층해수로 배양한 시료의 조 단백질 및 회분의 함량은 각각 $27.20,26.30$ 및 $21.19,22.17 \%$ 였 으며, 해양심층수와 표층해수에 따른 차이는 크지 않는 것으 로 확인되었다. 한편, 조지방 및 탄수화물의 함량은 해양심층 수를 사용 시료가 각각 $37.09,12.16 \%$ 였고 표층해수를 사용한 시료는 $35.76,13.20 \%$ 로 해양심층수로 배양한 시료가 조지방 함량이 약간 높은 값을 나타내었다. Brown and Jeffrey (1992) 의 보고에 따르면, 담수산 녹조류인 Chlorophyceae와 해수산 녹조류인 Chlorophyceae 및 Prasinophyceae의 일반성분 함량 이 건조중량으로 단백질은 $15.2-25.6 \%$, 탄수화물은 10.8 $16.7 \%$, 지방은 $8.5-18.4 \%$ 범위였다고 보고한 바 있다. 본 실험 의 Tetraselmis sp. JK-46의 탄수화물과 단백질 함량은 비슷한 경향을 나타내었지만 지방 함량이 매우 높은 것이 특징적이었 
으며, 성분 함량은 해양심층수와 표층해수를 사용한 두 경우 모두 큰 차이가 없었다.

\section{무기질 함량}

해양심층수와 표층해수를 사용하여 배양한 Tetraselmis sp. $\mathrm{JK}-46$ 의 무기질 함량을 분석한 결과 (Table 2), 해양심층수로 배양한 시료의 마그네슘, 칼슘, 철 및 칼륨 함량은 각각 $7,080.33,1,009.60,251.17,2,749.67 \mathrm{mg} / 100 \mathrm{~g}$ 이었고, 표층해수 로 배양한 것은 각각 $7,770.00,1,190.67,341.07$ 및 $2,557.00$ $\mathrm{mg} / 100 \mathrm{~g}$ 이었다. 그 외에 망간, 구리, 아연 및 알루미늄 등이 소량 함유되어 있었다. 표층해수로 배양한 Tetraselmis sp. $\mathrm{JK}-46$ 이 해양심층수로 배양한 것보다 마그네슘, 칼슘, 철 등의 함량이 높았으며, 칼륨 함량은 해양심층수로 배양한 것이 더 높은 값을 나타났다. Kim et al. (2001)은 녹조강인 Nostoc oculata와 규조강인 Phaeodactylum tricornutum 의 무기질을 분 석한 결과, N. oculata는 칼륨, 마그네슘, 칼슘 및 철의 함량이 각각 $12,906.86,1,039.15,882.57$ 및 $747.20 \mathrm{mg} / 100 \mathrm{~g}$ 이었으며, P. tricomutum 은 칼륨, 마그네슘, 칼슘 및 철의 함량이 각각 $11,718.65,2,003.32,1,580.84$ 및 $552.58 \mathrm{mg} / 100 \mathrm{~g}$ 이 함유되어 있다고 보고한 바 있다. 그러나 Shimma et al. (1984)은 부착성 미세조류의 무기질 함량 중에서 칼륨, 칼슘, 마그네슘의 함량 이 각각 540-730, 450-520, 370-420 mg/100 g으로 보고한 바 있는데, 이들에 비해서는 칼륨, 마그네슘, 칼슘 함량이 높은 것으로 나타났다. 한편, 실험에 사용한 해양심층수 및 표층해 수의 무기질 함량은 해양심층수가 $\mathrm{Mg}$ 함량이 약간 높은 것이 특징적이었고, 그 외 $\mathrm{Na}, \mathrm{K}, \mathrm{Fe}$ 등의 함량은 비슷하였다. 이는 해양심층수와 표층수의 무기질 함량이 배양 미세조류의 무기 질 함량에 영향을 미치는 것은 명확하게 예측할 수 없었다. 다만 유기질소 및 인과 같은 미세조류의 성장과 관련된 성분 이 많은 해양심층수가 성장 및 무기질 성분의 차이에 영향을 미치는 것으로 판단되었다.

Table 2. Mineral compositions of Tetraselmis sp. JK-46 using surface seawater and deep seawater as culture medium

\begin{tabular}{ccc} 
& & $(\mathrm{mg} / 100 \mathrm{~g})$ \\
\hline Minerals & Surface seawater & Deep seawater \\
\hline $\mathrm{Mg}$ & $1,770.00$ & $1,080.33$ \\
$\mathrm{Ca}$ & $1,190.67$ & $1,009.60$ \\
$\mathrm{Mn}$ & 14.45 & 11.77 \\
$\mathrm{Fe}$ & 341.07 & 251.17 \\
$\mathrm{Cu}$ & 3.33 & - \\
$\mathrm{Zn}$ & 10.75 & 1.67 \\
$\mathrm{Al}$ & 8.63 & 3.27 \\
$\mathrm{~K}$ & $2,557.00$ & $2,749.67$ \\
\hline
\end{tabular}

지방산 조성

미세조류의 지방산 조성은 미세조류 종뿐만 아니라 배지조 성, 공기주입속도, 빛강도, 광주기 기간, 온도와 배양시간 등의 배양조건과 관련된 인자에 의존한다고 하였다 (Robles medina et al., 1998). 해양심층수 및 표층해수로 배양한 Tetraselmis sp. JK-46의 지방산 조성 분석 결과를 Table 3에 나타내었다. 해양심층수로 배양한 경우 포화 지방산, 단일불포화 지방산 및 다가불포화 지방산의 함량은 각각 $25.65,20.68$ 및 53.67 $\%$ 였고, 표층해수로 배양한 시료는 각각 $30.71,20.25$ 및 49.04 $\%$ 로 다소 차이를 나타내었다. 해양심층수로 배양한 시료의 경우 고도불포화 지방산의 함량이 표층해수로 배양한 시료보 다 약 $4.6 \%$ 높은 값을 나타내었다. 또한 필수지방산인 linoleic acid $(18: 2, n-6)$ 와 linolenic acid (18:3, n-3)의 함량과 생리기능 적으로 중요한 다가불포화 지방산 중 $\mathrm{EPA}(20: 5, \mathrm{n}-3)$ 와 DHA $(22: 6, n-3)$ 의 함량은 해양심층수로 배양한 것은 8.04 및 3.66 $\%$ 였고, 표층해수로 배양한 시료는 9.44 및 $0.51 \%$ 로 해양심층 수와 표층해수 시료간에는 약간의 차이를 나타내었다. Tetraselmis sp. JK-46은 대량배양과 수확이 간단하고 경제적이며 영양가 도 좋아 사료원으로 가장 넓게 이용되는데 미세조류를 사료원

Table 3. Fatty acid compositions of Tetraselmis sp. JK-46 using surface seawater and deep seawater as culture medium

(Area \%)

\begin{tabular}{|c|c|c|}
\hline Fatty acids & Surface seawater & Deep seawater \\
\hline $12: 0$ & 1.55 & 0.19 \\
\hline $13: 0$ & - & 0.24 \\
\hline $14: 0$ & 1.82 & 1.07 \\
\hline $15: 0$ & - & - \\
\hline $16: 0$ & 24.13 & 16.51 \\
\hline $17: 0$ & 0.72 & 0.80 \\
\hline $18: 0$ & 1.23 & 1.23 \\
\hline $20: 0$ & 0.84 & 1.25 \\
\hline $21: 0$ & - & 0.68 \\
\hline $22: 0$ & 0.42 & 1.36 \\
\hline $23: 0$ & - & 1.39 \\
\hline $24: 0$ & - & 0.93 \\
\hline $16: 1(n-7)$ & 5.46 & 4.44 \\
\hline $17: 1(n-7)$ & - & 0.29 \\
\hline $18: 1(\mathrm{~T})$ & - & 0.56 \\
\hline $18: 1(C)$ & 13.13 & 10.29 \\
\hline $20: 1(n-9)$ & 1.66 & 1.83 \\
\hline $22: 1(n-9)$ & - & 1.67 \\
\hline $24: 1(n-5)$ & - & 1.60 \\
\hline $18: 2(\mathrm{~T})$ & 10.40 & 8.14 \\
\hline $18: 2(C)$ & 9.35 & 6.48 \\
\hline $18: 3(n-3)$ & 16.41 & 13.46 \\
\hline $18: 3(n-6)$ & 0.80 & 1.43 \\
\hline $20: 2(n-6)$ & - & 6.01 \\
\hline $20: 3(n-6)$ & 0.48 & 2.31 \\
\hline $20: 3(n-3)$ & - & 1.27 \\
\hline $20: 4(n-6)$ & 0.87 & 2.01 \\
\hline $20: 5(n-3)$ & 9.44 & 8.04 \\
\hline $22: 2(n-6)$ & 0.78 & 0.86 \\
\hline $22: 6(n-3)$ & 0.51 & 3.66 \\
\hline Saturated fatty acids (SFA) & 30.71 & 25.65 \\
\hline Monoenoic fatty acids (MUFA) & 20.25 & 20.68 \\
\hline Polyenoic fatty acids (PUFA) & 49.04 & 53.67 \\
\hline Total & 100 & 100 \\
\hline
\end{tabular}


으로서 이용하는데 있어 지방산 조성은 배양 유기물의 생존과 성장에 매우 중요한 역할을 하게 되는 것으로 알려져 있다 (Watanabe et al. 1983). 해양심층수로 배양한 Tetraselmis sp. JK-46의 다가불포화 지방산 함량이 표층해수로 배양한 시료 에서 더 높게 나타남으로서 해양심층수의 배양 배지 소재로서 의 활용이 기대된다.

Table 4. Amino acid compositions of Tetraselmis sp. JK-46 using surface seawater and deep seawater as culture medium

(A.A mg/100 g)

\begin{tabular}{lcc}
\hline \multicolumn{1}{c}{ Amino acids } & Surface seawater & Deep seawater \\
\hline Aspartic acid & $603.3(9.46)$ & $798.7(10.80)$ \\
Threonine & $282.8(4.43)$ & $358.1(4.84)$ \\
Serine & $266.1(4.17)$ & $346.6(4.69)$ \\
Glutamic acid & $980.1(15.37)$ & $1,221.4(16.52)$ \\
Proline & $319.4(5.01)$ & $441.7(5.98)$ \\
Glycine & $362.8(5.69)$ & $459.9(6.22)$ \\
Alanine & $471.6(7.40)$ & $62.8(0.85)$ \\
Valine & $403.2(6.32)$ & $510.0(6.90)$ \\
Methionine & $145.4(2.28)$ & $258.0(3.49)$ \\
Cystine & $100.6(1.58)$ & $18.2(0.25)$ \\
Isoleucine & $286.2(4.49)$ & $356.9(4.83)$ \\
Leucine & $513.5(8.05)$ & $648.4(8.77)$ \\
Tyrosine & $222.7(3.49)$ & $287.4(3.89)$ \\
Phenylalanine & $327.2(5.13)$ & $405.9(5.49)$ \\
Histidine & $119.3(1.87)$ & $149.8(2.03)$ \\
Lysine & $355.0(5.57)$ & $443.0(5.99)$ \\
Arginine & $616.7(9.67)$ & $626.1(8.47)$ \\
\hline Essential acids & $3,049.3(47.81)$ & $3,756.2(50.81)$ \\
\hline Total amino acids & $6,376.0(100)$ & $7,392.6(100)$ \\
\hline
\end{tabular}

\section{아미노산 조성}

Tetraselmis sp. JK-46의 총아미노산 조성을 분석한 결과는 Table 4와 같다. 해양심층수로 배양한 시료는 총아미노산 함량 이 $7392.6 \mathrm{mg} / 100 \mathrm{~g}$ 이었으며, 맛을 내는 주요 성분인 glutamic acid와 aspartic aicd가 각각 1221.4 와 $798.7 \mathrm{mg} / 100 \mathrm{~g}$ 로 가장 높은 함량을 차지하였다. 표층해수로 배양한 시료는 총아미노 산 함량은 $6376.0 \mathrm{mg} / 100 \mathrm{~g}$ 로 해양심층수로 배양한 시료보다 아미노산 함량이 낮은 것으로 확인되었고, 표층해수로 배양한 것도 glutamic acid와 aspartic aicd가 980.1 및 $603.9 \mathrm{mg} / 100$ $\mathrm{g}$ 로 가장 높은 함량을 차지하였다. 또한, 필수 아미노산 함량 에서도 해양심층수로 배양한 것이 $3756.2 \mathrm{mg} / 100 \mathrm{~g}$ 로 전체 아미노산 함량중에서 $50.81 \%$ 로 가장 높은 함량을 차지하였으 며, 표층해수로 배양한 시료의 $47.81 \%$ 보다 $3 \%$ 가량 높은 함량 을 나타내었다. Kim et al. (2001)이 보고한 N. oculata와 P. tricornutum 의 glutamic acid와 aspartic acid 함량과 거의 유사하 였으며 필수아미노산 함량도 각각 $46.31 \%$ 과 $45.51 \%$ 로 본 연 구 결과와 유사하였다.
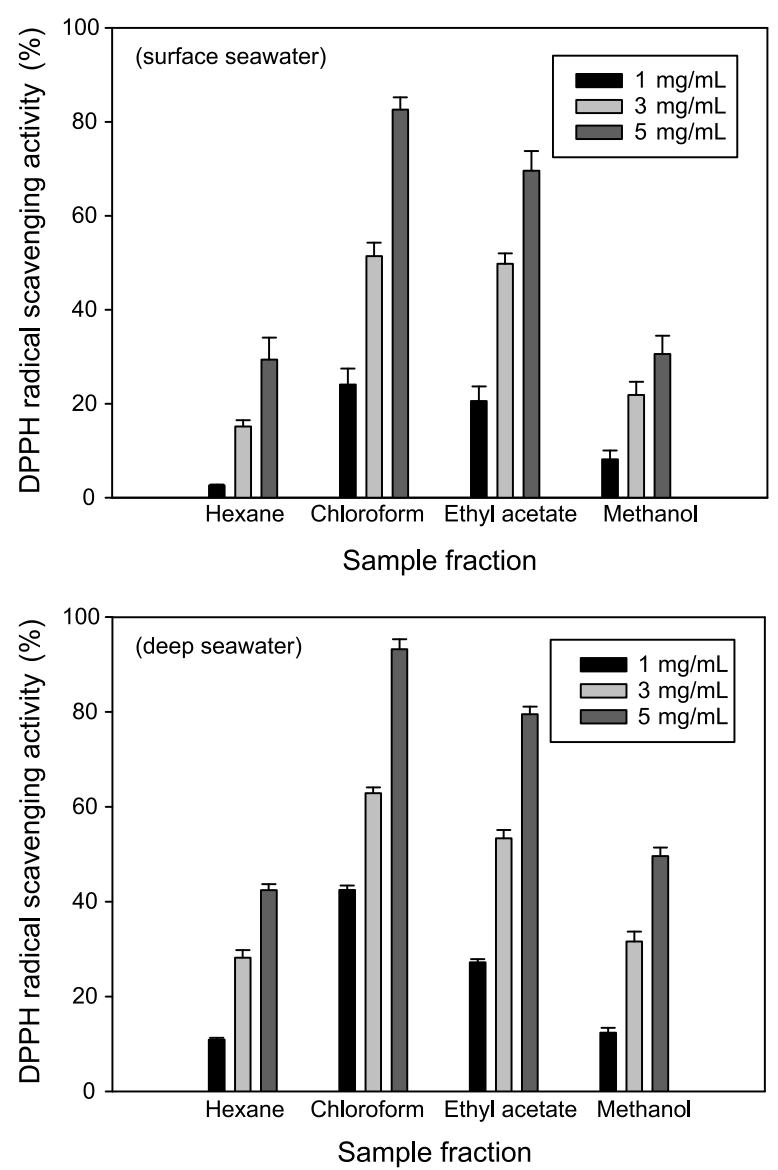

Fig. 2. DPPH radical scavenging activity of each fraction from silica gel chromatography of extracted sample from Tetraselmis sp. JK-46 cultured in surface seawater and deep seawater.

Tetraselmis sp. JK-46 추출성분의 생리활성

\section{항산화능}

배양 미세조류 추출물 및 이 시료로부터 얻어진 각 용매 획분의 DPPH 라디칼 소거능을 Fig. 2에 나타내었다. 해양심층 수 및 표층해수로 배양한 시료의 용매 추출물의 농도를 3.0 $\mathrm{mg} / \mathrm{mL}$ 로 조절하여 반응시킬 때 각각 48.5 및 $39.2 \%$ 의 항산화 능을 나타내었다. 시료의 농도를 $1 \mathrm{mg} / \mathrm{mL}, 3 \mathrm{mg} / \mathrm{mL}, 5 \mathrm{mg} / \mathrm{mL}$ 로 조절하여 각 용매 획분별 항산화능을 실험한 결과, 해양심 층수 시료의 경우는 chloroform층에서 농도별 유의성을 가지 면서 가장 강한 항산화효과를 나타내었으며, 다음으로 ethyl acetate층이 높은 항산화효과를 보였다. 표층해수로 배양한 시료에서도 경향은 해양심층수로 배양한 시료와 유사하였으 나 항산화효과는 낮은 것으로 확인되었다. 농도에 따른 효과 가 확실했던 chloroform층과 ethyl acetate층에 대한 $\mathrm{IC}_{50}$ 을 확인한 결과 (Table 5), 해양심층수 및 표층해수로 배양한 chloroform층이 각각 $1.2 \mathrm{mg} / \mathrm{mL}, 2.6 \mathrm{mg} / \mathrm{mL}$ 이었고, ethyl acetate층은 각각 $3.1 \mathrm{mg} / \mathrm{mL}, 3.3 \mathrm{mg} / \mathrm{mL}$ 로 해양심층수 시료가 상대적으로 강한 항산화 활성을 나타내었다. 미세조류가 생산 
하는 지용성 색소나 polyphenol성 화합물, chlorogenic acid 등 과 같은 성분이 항산화 효과와 연관성이 있는 것으로 해석되 고 있다 (Choi et al., 2000; Kim et al., 1997).

항혈액응고활성

배양 미세조류 추출물 및 이 시료로부터 얻어진 각 용매 획분의 항혈액응고활성을 Fig. 3 에 나타내었다. 항산화능 결 과와는 달리 해양심층수 및 표층해수로 배양한 시료 대부분이
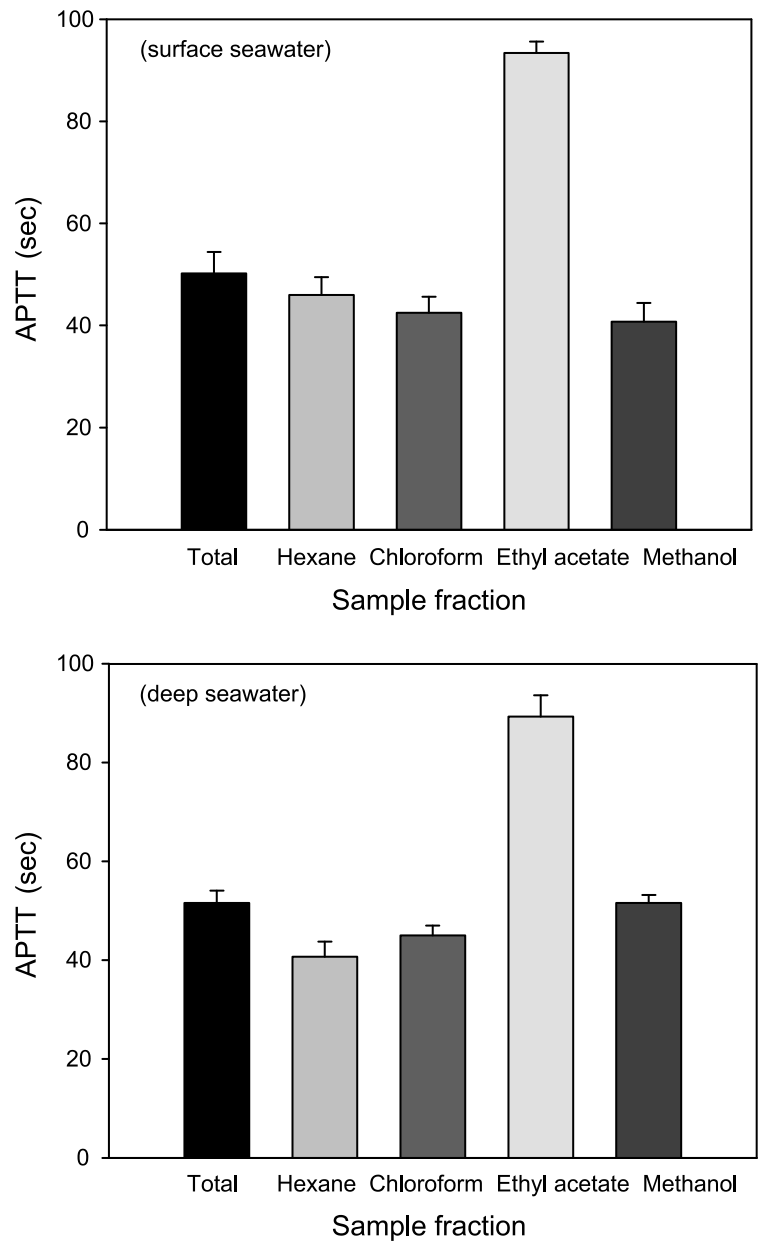

Fig. 3. Anticoagulant activity of each fraction from silica gel chromatography of extracted sample from Tetraselmis $\mathrm{sp}$. JK-46 cultured in surface seawater and deep seawater.

Table 5. $\mathrm{IC}_{50}$ value of DPPH radical scavenging activity of each fraction from silica gel chromatography of extracted sample from Tetraselmis sp. JK-46 cultured in surface seawater and deep seawater

\begin{tabular}{|c|c|c|}
\hline \multirow{2}{*}{ Sample fraction } & \multicolumn{2}{|c|}{$\mathrm{IC}_{50}$ value $(\mathrm{mg} / \mathrm{mL})$} \\
\hline & Surface seawater & Deep seawater \\
\hline Hexane & - & - \\
\hline Chloroform & 2.6 & 1.2 \\
\hline Ethyl acetate & 3.3 & 3.1 \\
\hline Methanol & - & - \\
\hline
\end{tabular}

hexane, chloroform 및 methanol 획분에서는 항혈액응고활성 이 미약하였고, ethyl acetate 획분만 APTT가 각각 $93.4 \mathrm{sec}$ 및 $89.3 \mathrm{sec}$ 로 활성을 나타내었다. 미세조류 성분의 항혈액응 고활성에 대한 보고는 없지만 미세조류에서 황화합물의 축적 이 일어나는데 이러한 성분들이 혈액응고를 지연시키는 효과 가 있는 것으로 여겨진다.

Table 6. Antimicrobial activity of each fraction from silica gel chromatography of extracted sample from Tetraselmis sp. JK-46 strain cultured in surface seawater

\begin{tabular}{|c|c|c|c|c|c|c|c|c|c|c|}
\hline \multirow{3}{*}{$\begin{array}{c}\text { Extraction } \\
\text { solvent }\end{array}$} & \multicolumn{10}{|c|}{ Test strain } \\
\hline & \multicolumn{2}{|c|}{ E. coli } & \multicolumn{2}{|c|}{ B. subtilis } & \multicolumn{2}{|c|}{ St. aureus } & \multicolumn{2}{|c|}{$\begin{array}{c}\text { Can. } \\
\text { albicans }\end{array}$} & \multirow{2}{*}{$\begin{array}{r}\text { Asp. } \\
25\end{array}$} & \multirow{2}{*}{$\begin{array}{c}\text { niger } \\
45\end{array}$} \\
\hline & $25^{11}$ & 45 & 25 & 45 & 25 & 45 & 25 & 45 & & \\
\hline Tota & - & - & +- & +- & - & - & - & - & - & - \\
\hline Hexane & - & - & - & - & - & - & - & - & - & - \\
\hline $\mathrm{CHCl}_{3}$ & -2) $^{2}$ & +- & - & +- & - & - & - & +- & - & - \\
\hline EtOAc & - & - & +- & +- & - & - & - & - & - & - \\
\hline $\mathrm{MeOH}$ & - & - & - & - & - & - & - & - & - & - \\
\hline
\end{tabular}

${ }^{1)}$ Sample injection volume $(\mu \mathrm{L})$.

${ }^{2)}$ Diameter of inhibition zone : -, no inhibition; +-, 8 10 mm; +, 10 15 mm; ++, 15 20 mm; +++, more than $20 \mathrm{~mm}$

\section{항균활성}

배양 미세조류 추출물 및 이 시료로부터 얻어진 각 용매 획분의 항균활성을 Table 6와 Table 7에 나타내었다. 실험에 사용한 세균은 식품부패와 식중독 유발과 관련된 균을 선정하 였고, 효모와 곰팡이 식품 부패와 관련된 균을 활용하였다. 그 결과 해양심층수로 배양한 시료의 경우, chloroform 획분과 ethyl acetate 획분에서 주로 항균 활성을 나타내었다. 세균인 B. subtilis, E. coli에 항균활성은 물론이고 효모인 Can. albicans 에 대해 항균활성이 확인되었으며, 표층해수로 배양한 시료에 서도 항균효과는 낮았지만 유사한 경향을 나타내었다. 특히 chloroform 획분은 B. subtilis에서 강한 항균활성을 나타내었 으며, Ethyl acetate 획분은 Can. albican에서도 활성을 나타내 었다. 항균활성은 해양심층수로 배양한 시료에서 더 강한 활 성을 나타내는 것으로 확인되었다. Joo et al. (1998)에 의하면 해양 미세조류로부터 강력한 항균 활성 물질들이 발견된다고 보고하고 있다.

Table 7. Antimicrobial activity of each fraction from silica gel chromatography of extracted sample from Tetraselmis sp. JK-46 strain cultured in deep seawater

\begin{tabular}{|c|c|c|c|c|c|c|c|c|c|c|}
\hline \multirow{3}{*}{$\begin{array}{c}\text { Extraction } \\
\text { solvent }\end{array}$} & \multicolumn{10}{|c|}{ Test strain } \\
\hline & \multicolumn{2}{|c|}{ E. coli } & \multicolumn{2}{|c|}{ B. subtilis } & \multicolumn{2}{|c|}{ St. aureus } & \multicolumn{2}{|c|}{$\begin{array}{c}\text { Can. } \\
\text { albicans }\end{array}$} & \multirow{2}{*}{$\begin{array}{c}\text { Asp. } \\
25\end{array}$} & \multirow{2}{*}{$\frac{\text { niger }}{45}$} \\
\hline & $25^{11}$ & 45 & 25 & 45 & 25 & 45 & 25 & 45 & & \\
\hline Total & - & +- & + & + & - & - & - & - & - & - \\
\hline Hexane & - & - & - & - & - & - & - & - & - & - \\
\hline $\mathrm{CHCl}_{3}$ & $+-^{2)}$ & +- & ++ & ++ & - & - & - & +- & - & - \\
\hline EtOAc & - & +- & + & + & - & - & - & +- & - & - \\
\hline $\mathrm{MeOH}$ & - & - & - & - & - & - & - & - & - & - \\
\hline
\end{tabular}




\section{사 사 \\ 본 연구는 산업자원부 지정 강릉대학교 RIC (동해안해양생 물자원연구센터) 연구과제지원에 의해 수행되었으며 이에 감 사드립니다.}

\section{참고문헌}

AOAC. Offical Methods of Analysis. 16th ed. 1995. Association of Official Analytical Chemists, Washington DC., U.S.A., 69-74.

Borowitzka MA. 1997. Microalgae for aquaculture: opportunities and constraints. J Appl Phycol 9, 393-401.

Brown MR and Jeffrey SW. 1992. Biochemical composition of microalgae from the green algal classes Chlorophyceae and Prasinophyceae. 1. Amino acids, sugars and pigments. J Exp Mar Biol Ecol 161, 91-113.

Choi JS, Lee WK, Son BW, Kim DS, Choi HD, Choi JS, Jung JH, Im KS and Choi WC. 2000. Screening on radical scavenging activity of marine microalgae. Kor J Pharmacogn 31, 252-255.

Dionisi F, Golay PA, Elli M and Fay LB. 1993. Stability of cyclopropane and conjugated linoleic acids during fatty acid quantification in lactic acid bacteria. Lipids 34, 1107-1115.

Guillard RRL. 1975. Division rates. In: stein J.R.(ed), Handbook of phycological methods-culture methods and growth measurements. Cambridge University Press, Cambridge, U.S.A., 289-311.

Hatano T, Kagawa H and Okawa T. 1988. Two new flavonoids and other constituents in licorice wet: their relative astringency and radical scavening effect. Chem Pharm Bull 36, 2090-2097.

John DB. 1982. Clinical Laboratory Methods. Ninth Edition. The C.V. Mosby company. St. Louis, U.S.A., 294-296.

Joo DS and Lee EH. 1998. Searching of antimicrobial active compounds from microalgae. Kor Soc Life Sci 8, 173-180.

Jorian V. 1991. Antibiotics laboratory medicine, Williams
\& Wilkins, Baltimore. U.S.A., 17-105

Kim SK, Baek HC, Byun HG, Kang OJ and Kim JB. 2001. Biochemical composition and antioxidative activity of marine microalgae. J Kor Fish Soc 34, 260-267.

Kim ML, Jeong JS, Lee MH and Lee GD. 2003. Effects of deep seawater and salt on the quality characteristics of breads. Kor J Food Pres 10, 326-332.

Kim SS, Lee CK, Kang SS, Jung HA and Choi JS. 1997. Chlorogenic acid, an antioxidant principle from the aerial parts of Artemisia iwayomogi that acts on DPPH radicak. Arch Pharm Res 20, 148-154.

Korea ocean reserch lab. 2000. feasibility study for the multipurpose development of deep ocean water resource. MOMAF Report UCM, 00903-2284.

Laurent D, Patrick G, Yaron A, Shoshana MA, Philippe B, Kotamballi NCM and Gokare AR. 2005. Microorganisms and microalgae as sources of pigments for food use: a scientific oddity or an industrial reality. Trends Food Sci Technol 16, 389406.

Park EK, Seo MW and Lee CG. 2001. Effect of medium compositions for the growth and the astaxanthin production of Hamatococcus pluviatis. Kor J Appl Microbiol Biotechnol 29, 227-233.

Robles medina A, Molina grima E, Giménez giménez and Ibáñez gonzález MJ. 1998. Downstream processing of algal polyunsaturated fatty acids. Biotechnol Adv 16, 517-580.

Shimma Y, Tanaka H, Huruta Y, Shimma H and Ikeda K. 1984. Protein, carotenoid and mineral contents and fatty acids composition of the sessile algae from Chikuma river. Bull Jap Soc 50, 1223-1227.

Takahashi M. 2001. It knows and the deep sea water. Doseo publication, Science and technology 23, 35-37.

Watanabe T, Kitajima C and Jujita S. 1983. Nutrition value of live organisms used in Japan for mass propagation of fish: A review. Aquaculture 34, 115-143.

2010년 10월 22일 접수

2010년 11월 22일 수정

2011년 2월 10일 수리 